Nuntius Antiquus, Belo Horizonte, v. 11, n. 1, p. 137-172, 2015

\title{
O jogo elegíaco: fronteiras entre a cultura intelectual e a ficção poética
}

\section{The elegiac game: borders between intellectual culture and poetic fiction}

Paulo Martins

Universidade de São Paulo (USP), São Paulo, São Paulo, Brasil.

paulomar@usp.br

Resumo: O objetivo deste artigo é apontar alguns elementos referenciais de cultura intelectual, associando-os aos ficcionais da elegia erótica romana. Esta relação esclarece, a meu ver, "o jogo elegíaco", isto é, o conceito descrito por P. Veyne em L'élégie érotique romaine (1983), que indica o contato constante entre dados reais e ficcionais nela expressos, além dos efeitos de sentido produzidos na recepção a partir deste contato.Tal mecanismo, acredito, pode ser considerado como a principal característica da elegia erótica romana. Assim, este trabalho parte de uma das teses apresentadas por Veyne (1983), tendo em vista as críticas de G. B. Conte (1986) e pósteros, buscando apresentar novas colaborações para a compreensão deste gênero poético.

Palavras-chave: elegia romana; Propércio; cultura intelectual; ficção; realidade. 
Abstract: The aim of this article is to point out some referential elements of intellectual culture in association with fictional elements in Roman love elegy. This relationship clarifies "the elegiac game", i.e., the concept described by P. Veyne in L'élégie érotique romaine (1983) which concerns the constant contact between real and fictional referents in Roman elegy, as well as the effects produced in the audience by it. Such device, I believe, can be considered as the main feature of Roman love elegy. Thus, this paper revaluates one of Veyne's theses, taking into account G. B. Conte (1986) and later scholars' criticism, in an effort to present a new contribution to the comprehension of this poetic genre. Keywords: Roman elegy; Propertius; intellectual culture; fiction; reality.

Recebido em 29 de maio de 2015. Aprovado em 17 de junho de 2015.

\section{Estado da questão}

Em que pesem as polêmicas envolvendo o livro de Paul Veyne $-A$ elegia erótica romana - nos últimos trinta anos, dele podemos colher uma tese importante que acredito estar na base da especificidade genérica da elegia erótica em Roma. Afastada daquela elegia grega arcaica, clássica ou helenística, ou do epigrama, que também se valeu do dístico elegíaco, algo tipicamente romano a caracteriza. Se observarmos o que nos propõe Farrell, quando contrasta a elegia erótica romana com a helenística de Calímaco e de Filetas, nota-se claramente a distância que as separa - ainda que essa poesia em Roma seja, sim, devedora em muitos aspectos da elegia helenística - e também se vislumbram algumas características próprias:

If, however, we define Roman elegy as the kind of poetry that Gallus, Tibullus, Propertius, and Ovid wrote, we find that it is very different. All of them wrote in the first person, each about a love affair with a particular woman (or, in Tibullus' case, with two different women successively). The names of these women suggest Greek culture and sophistication. The women themselves are represented as lacking the status of citizen birth and living off their attractiveness to the kind of men the poets make 
themselves out to be. The persona of the lover boats a literary culture beyond any rival and just enough wealth that actual work never enters into consideration, but not so much that he fails to resent the lady's demands for gifts - the main area in which those less cultivated rivals actually can surpass him. The poet/lover therefore lives in a state of constant jealousy, enthrallment, and inability to satisfy the whims of his domina - his "mistress" in more than the modern sense because the word connotes actual domination, as over a slave. (FARRELL, 2012, p.13)

Entretanto, mesmo observando essas características, digamos, típicas da elegia romana augustana, parece-me que podemos encontrar ainda algo ainda mais preciso que caracterize este gênero poético romano, e isso está indicado em uma das teses de Veyne: o jogo elegíaco. Esta marca, a meu ver, emoldura este gênero poético em sua expressão latina, o enquadra sob perspectiva pragmática, imprimindo-lhe características específicas que podem tipificá-lo como gênero singular, diferente, portanto, do gênero afim e/ou confim de expressão grega. Por sua vez, não questiono aqui a validade de algumas afirmações de Veyne, como faz Vasconcellos (VASCONCELLOS, 2011, p. 105-118), que nos apresenta, de forma precisa, pontos positivos e, principalmente, negativos sobre o trabalho do historiador, elencando, de um lado, argumentos de Wyke (1989b), Fitzgerald (1995), Gibson (2005) e, de outro, os de Conte (1986), estes, sim, tão cristalizados quanto inflexíveis a respeito desse livro do historiador francês ${ }^{1}$ e não aqueles. Preocupa-me como podemos entender esse enquadramento genérico particular e específico que, a despeito de pontos contestáveis, ou melhor, controversos, estão na base da elegia de Propércio, Tibulo e Ovídio e foram apontados por Veyne.

A crítica biografista, combatida por ele, ao contrário do que afirma Vasconcellos, não possuía, em meados dos anos 80 e mesmo hoje, apenas alguns defensores ou epígonos que "continuam, aqui e ali, sobrevivendo nos dias de hoje" (VASCONCELLOS, 2011, p.108), ou ainda, ao contrário do que diz Conte ao propor que "é também verdade que a melhor crítica não acredita mais nisso, ${ }^{2}$ e há tempo". Antes, a meu ver, ela

${ }^{1}$ CONTE, 1986 (apud VASCONCELLOS, 2011, p. 107): "O autor se criou um ídolo polêmico, mas há tempos o ídolo tem apenas uns poucos e negligenciáveis adoradores". ${ }^{2}$ No biografismo (nota nossa). 
continua viva e tem papel relevante dentro e fora do círculo filológico, uma vez que os textos que a embasam como tese de fundo - claramente de viés positivista e determinista - continuam circulando e, sistematicamente, são elencados em trabalhos acadêmicos, no Brasil e no exterior. Assim informa James (2010, p. 314, n.1): "Maria Wyke and others have established the puella as a poetic construct rather than any historical woman, but biographism continues to haunt elegy studies". Em um trabalho anterior (MARTINS, 2008a), aponto alguns desses trabalhos e critico seu uso tanto em sala de aula como em textos de grau. ${ }^{3}$ Em meu mestrado de 1996 e no livro que dele resultou, acompanho Veyne, apontando particularidades do discurso elegíaco, embora o enquadre sob a tutela de uma retórica e de uma poética elegíacas, às quais o historiador não se reportou, a não ser subliminarmente, ${ }^{4}$ e que ainda hoje servem para esquadrinhar este gênero poético (MARTINS, 2009, p. 21-39). Veyne, como em outros momentos de sua trajetória intelectual, apoia-se em Foucault e, assim, desvencilha-se de categorias que estão na base da ideia de continuidade, como tradição, influência, desenvolvimento e evolução, mentalidade e espírito (FOUCAULT, 1995, p. 23-24), ocupando-se restritivamente de um gênero específico em três autores de um mesmo período, cuja circulação, se não a mesma, era muito semelhante e próxima. O historiador, portanto, trata do texto elegíaco observando sua textualidade, isto é, um discurso que é regulado por mecanismos que lhe são próprios e são apreendidos por seus leitores e/ou ouvintes, em outras palavras, preocupa a Veyne a textualidade narrativa das elegias.

Assim, Paul Veyne busca, a meu ver, recuperar a pragmática discursiva da elegia latina, tendo em vista sua recepção coetânea à

\footnotetext{
${ }^{3}$ Em MARTINS, 2008a, passim, propus a leitura de E. Bickell, E. Paratore, entre outros. Quanto aos dois primeiros, uma rápida busca no Google Acadêmico demonstra um razoável impacto das obras criticadas por mim em 2008, hoje em dia. Para a tradução espanhola do livro de Bickell temos 80 citações, para o original Lehrbuch der Geschichte der römischen Literatur, 30 citações. No caso de Paratore, para a tradução portuguesa, somam-se 157 citações e para o original italiano Storia dela letteratura latina, temos 47. Tais índices de impacto foram observados para os últimos 5 anos, o que agrava minha argumentação.

${ }^{4}$ Penso aqui na apresentação dos argumentos de Allen (1950), que aponta a existência de termos de identificação estilística como contra-argumento à tese de "sinceridade" elegíaca, logo uma tese, essencialmente biografista, refutada sob a perspectiva de Quintiliano, por exemplo.
} 
composição, e como as marcas discursivas advindas desta pragmática perpassam transistoricamente a recepção, atingindo não só os romanos do século de Augusto, como também recepção variada nos séculos 19, 20 e 21 . Lowie propõe uma boa reflexão sobre pragmática literária, isto é, a relação entre literatura e aquilo que representa (LOWRIE, 2005, p. 39-43), assentando seus argumentos nas bases organizadas por Barchiesi que, apesar de não usar o termo "pragmática", salienta três características da poesia augustana, tendo em vista o binômio poesia e aquilo que ela representa: a) a "tematização" ou "dramatização" de um gênero, isto é, quando um tema é produto e, ao mesmo tempo, condição-problema para o mesmo texto; b) um sentido de "fenda e perda", quando o gênero rompe com momentos de verdade, isto é, quando oscila entre a matriz real internalizada e uma visão regressiva do gênero como deveria ser e c) a "politização", quando as divisões genéricas assumem valores políticos e sociais específicos, por exemplo, quando uma discussão sobre a contenda poética épica versus elegia implica no significado do que vem a ser o Principado na literatura (BARCHIESI, 2000, p. 167). Portanto, a pragmática a que me refiro é justamente a ideia que subjaz a certo jaez genérico em sua relação com o mundo em que está inserido o texto literário, no nosso caso específico, a elegia de Propércio.

Diversamente do que pensa Vasconcellos, ${ }^{5}$ Veyne possui, sim, todo o instrumental técnico para decifrar o discurso dos poetas elegíacos romanos, ainda que não seja um "filólogo". ${ }^{6}$ Afinal, ele nos apresenta a ideia de que a construção das personae elegíacas, por serem constituídas poeticamente sempre da mesma forma, confirma uma matriz compositiva, que nos faz compreender que a recepção previamente reconhecia o procedimento poético de composição. Este conhecimento, que era adquirido por intermédio da sua instrução, estava, por um lado, na base constitutiva prévia necessária à elaboração dos éthe elegíacos pelo poeta ${ }^{7}$

\footnotetext{
${ }^{5}$ Vasconcellos (2011, p. 110): "Veyne diz que o leitor estava ciente do caráter ficcional da elegia, mas como se pode afirmar isso? É possível, então, traçar um quadro tão preciso e monolítico da recepção do discurso elegíaco e da poesia amorosa em geral?" ${ }^{6}$ Conte (1986) apud Vasconcellos (2011, p. 107): "Tenho bastante simpatia pela posição cultural do autor para não desejar tirar proveito de algum cochilo filológico".

${ }^{7}$ Ainda que não tenhamos tantas informações sobre a formação retórica de Propércio, quanto temos sobre Ovídio, devemos pensar como Reinhardt (2006, p. 200) adverte: "Propertius may have enjoyed, and just refer to the communis opinio that, even if ancient sources suggest that declamation became prominent only in the second half
} 
e, por outro, era conteúdo educacional partilhado pela recepção. Sua tese, a de Veyne, parece-me, preocupa-se com o(s) efeito(s) de sentido que os poetas buscam produzir com sua prática literária, de sorte que reconhece, de um lado, a recepção retórica e poeticamente apta, de outro, instaura o lugar necessário da construção poética, a saber, o limiar, a fronteira diáfana entre o real e a ficção. Assim, não acato a proposição de Conte que diz:

O estudioso francês pareceria acreditar ainda que existe uma literatura que procura o "verdadeiro e real" por si próprio e não pelos efeitos literários que ele pode produzir naquele artefato que é o texto (e se isso é grave, torna-se mais grave, por certo, no caso de uma literatura como a antiga, tão subordinada às regras da codificação, tão frequentemente disposta segundo estereótipos temáticos e formais, tão difusamente atravessada por retóricas várias). (CONTE, 1986 apud VASCONCELLOS, 2011, p. 107)

Veyne, de maneira diametralmente oposta, afirma que o efeito da elegia é justamente um material poético lúdico, que assim pode ser entendido por estar apoiado no limiar entre o real e a ficção. "A elegia romana se assemelha a uma montagem de citações e de gritos do coração", e é justamente nessa montagem que ela é "enquadrada por outros materiais que a fazem perder o caráter real; o próprio movimento do poema, bem composto, retira-lhe até a aparência de uma confidência" (VEYNE, 1985, p.12-13). Conte entende que o ludus, que Veyne evidencia, converte o texto literário em algo pouco sério, realizado como simples brincadeira, o que obviamente é uma interpretação estranha ao historiador, e, principalmente, aos poetas elegíacos. Creio que ao jogo elegíaco proposto não se deve imprimir esse juízo de valor. $O$ jogo faz referência à própria operação da poesia amorosa ${ }^{8}$ realizada pelo poeta, como pode ser observado nestes exemplos, no primeiro caso uma elegia de Propércio ${ }^{9}$ e no segundo um epigrama de Marcial:

of the first century BC, in fact very similar exercises were customary already when Cicero was a young man".

${ }^{8}$ Ludo, ere, si, sum - OLD, 8: "To spend one's time idly or frivolously, amuse oneself, trifle; (esp. w. ref. to the writing of love poems and other of lighter forms of literary composition)".

${ }^{9}$ Apesar de levar em consideração a edição da OCT de Heyworth (2007) para o texto 
Haec quoque perfecto ludebat Iasone Varro,

Varro Leucadiae maxima flamma suae; haec quoque lasciui cantarunt scripta Catulli, Lesbia quis ipsa notior est Helena. ${ }^{10}$

e

Audemus saturas: Lucilius esse laboras

ludo leuis elegos: tu quoque ludis idem.

Quid minus esse potest? Epigrammata fingere coepi: hinc etiam petitur iam mea palma tibi. ${ }^{11}$

O que se nota no primeiro trecho é um paralelismo explícito entre o primeiro e o segundo dístico, tendo como suporte: a) a anáfora haec quoque (v. 85 e 87); b) a posição de abertura do segundo hemistíquio do hexâmetro dos verbos ludebat e cantarunt (v. 85 e 87); c) as amadas Leocádia e Lésbia (v. 86 e 88); d) os predicados das amadas, maxima flamma e ipsa notior Helena (v. 86 e 88). Fato é que ludo aqui está longe de ser a explicitação de carência de seriedade da poesia, antes ocupa o mesmo campo semântico do canto, -are, referenciado pelo tema amoroso. Curiosamente, Varrão, após compor seu Jasão (isto é, sua tradução de Apolônio de Rodes, logo uma poesia elevada, porquanto épica), dedicase a outro gênero, não elevado, cuja temática é seu fogo por Leocádia, da exata forma que Catulo tratou sua Lésbia e a tornou mais célebre que Helena de Troia. Nestes dois pares de dísticos, é interessante observar que tanto o verbo ludebat como o cantarunt apontam para um possível rebaixamento de gênero. No primeiro caso, pela épica de Jasão e no segundo, pela aproximação exemplar entre Lésbia e Helena.

Já o epigrama de Marcial, cuja temática é a emulação entre dois poetas, põe em relevo um elemento a mais que não está explícito em Propércio, já que lá apenas há associação entre ludo e cantar amor, e

de Propércio, sigo Fedeli (1984), alterado em 2005 quanto ao livro 2.

${ }^{10}$ PROPÉRCIO, 2.34.85-8: "Varrão também louvava essa poesia, acabado seu Jasão,/ Varrão, a maior flama de sua Leocádia;/ essa também cantaram os escritos do lascivo Catulo,/ uma Lésbia é mais conhecida que Helena".

${ }^{11}$ MARCIAL, 12.94.7-10: "Ousei nas sátiras: pretendes ser Lucílio./ Brinquei leve elegia: tu também./ O que é mais simples? Comecei nos epigramas/ e desde agora almejas minha palma". (trad. F. Cairolli) 
aqui o poeta indica precisamente o gênero em que se dá o ludus, isto é, na suave elegia, na elegia amorosa romana. Assim, "brinca" leuis elegos. Na verdade, não creio que a melhor tradução seja "brincar leve elegia", como, por exemplo, propôs Cairolli (2014, p. 447), mas, simplesmente, "componho suaves elegias" (Ludo leuis elegos),já que ocupa o mesmo eixo paradigmático de audemus saturas ou fingere epigrammata.

Ainda tomando por base a tese de fronteira a que me referi, Veyne nos diz:

A elegia, porém, não é um quadro do demi-monde (...) Ela não descreve nada em absoluto e não impõe a seus leitores que pensem na sociedade real; ela se passa num mundo de ficção onde as heroínas são também mulheres levianas, onde a realidade só é evocada por flashes, e por flashes pouco coerentes; de uma página a outra, Délia, Cíntia poderiam ser cortesãs, esposas adúlteras, mulheres livres; o mais frequentemente, não se sabe o que elas são e não se está preocupado com isso; são mulheres de vida irregular, é tudo. (...) Esta irregularidade não é uma parte da vida de nossos poetas e de sua suposta amante, mas uma peça de um sistema; ela representa a lei do gênero, desempenha um papel que chamamos de semiótico. Era apenas num segundo tempo, se se desse o trabalho de se interrogar, que o leitor podia relacionar esta ficção às esferas sociais um pouco livres da época; esta atribuição, aliás, não acrescentava nada à compreensão do poema. No máximo o leitor se divertia, vendo o quanto a ficção tinha embelezado a realidade. ${ }^{12}$ (VEYNE, 1985, p. 17)

Penso que o efeito de sentido produzido pela elegia, que é apresentado por Veyne, sob uma perspectiva filológica ou retórica está

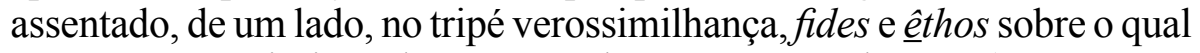
repousa a constituição da persona elegíaca, como observo (MARTINS, 2009, passim), e, de outro lado, no imiscuir-se dos referentes concretos da cultura intelectual e dos referentes ficcionais, a que ele, Veyne, chama de flashes, condizentes com os referentes do $1^{\circ}$ século a.C. e d.C., momento em que se insere esta produção poética. É de bom alvitre pensarmos também que além da tensão entre ficção e realidade em que

\footnotetext{
${ }^{12}$ Grifos nossos.
} 
está localizada a elegia romana, a inter-relação existente entre a persona ficta e a persona historica põe em evidência outra tensão. Dessa maneira, não só os elementos referenciais, fictícios e reais, em que se enquadra a elegia, como também os agentes que ocupam o espaço narrativo estão em constante tensão e todos a serviço da nequitia ${ }^{13}$ (SHARROCK, 2013, p. 151) da qual a elegia é veículo, seu suporte, digamos, cultural, que reflete um possível ou provável submundo ou um demi-monde verossímil do qual Veyne propõe serem as puellae elegíacas, ou, no caso de Propércio, Cynthia, e do qual os elegíacos se orgulham (OVÍDIO, Am. 2.1.1-2).

Ainda que sejam negadas as evidências de biografismo em nome da ficcionalidade ${ }^{14}$ das elegias, uma questão tem sido posta em jogo por alguns estudiosos, e diz respeito a crivar com autenticidade histórica certos destinatários masculinos da poesia erótica a fim de esclarecer as relações existentes entre esta poesia e o principado de Augusto. Assim, esses estudos tornariam mais precisos os flashes a que nos referimos anteriormente, além de salientar o contraste entre a ficcionalidade e a natureza histórica de certos dados apontados nas elegias a que chamei de referenciais. Nesse sentido, o trabalho de Wilson parece-me produtivo, já que busca nas elegias mapear as relações dos poetas com patronos e, finalmente, com o imperador, comprovando os indicativos de realidades históricas de hierarquia social, econômica e política sob Augusto, observando-se a convergência (ou divergência) dos temas dos poemas com a ideologia política de Augusto (WILSON, 2009, p. 173).

Nossa tarefa neste artigo é apontar alguns elementos referenciais da cultura intelectual em associação à ficcionalidade da elegia erótica romana, mapeando de forma mais precisa o jogo elegíaco e suas características específicas como gênero letrado tipicamente romano.

\footnotetext{
${ }^{13}$ Em português prefiro o sentido de "devassidão", diferentemente do uso em inglês badness.

${ }^{14}$ WALSH, 2003, p. 110-111: "The idea that fictionality and narrativity are in some sense coextensive is perhaps most strongly associated with a historian, Hayden White, although similar views are widespread among narrative theorists for whom fiction itself is the primary concern. Such views have more abstract and more fundamental implications than the mere questioning of the generic borders between (for instance) fiction and history. The force of the equation between narrativity and fictionality derives from the recognition that very little of the meaningfulness of narrative can be seen as independent of the artifice of narrativization".
} 


\section{Persona ficta $\mathrm{x}$ persona historica}

Uma das maiores curiosidades dos primeiro livros de Propércio é a variedade de interlocutores, de personae elegiacae que são oferecidas aos leitores de modo a reproduzir discursiva e narrativamente uma situação de fala verossímil, logo, de uma circunstância absolutamente pragmática, se pensarmos linguisticamente o discurso. Assim, a despeito do tema de que trata a poesia endemicamente - falo de um gênero específico -, Propércio nos põe em contato com interlocutores que, tendo em vista sua proposição em vocativo, são apresentados segundo um juízo de valor do enunciador, o poeta, vez por outra associado ao seu próprio nome. Além de referendar ou subverter uma imagem real ou construir uma persona sem referente real e, logo, ficcional por excelência, o leitor se informa acerca de quem é posto em jogo no enunciado do poema. $\mathrm{O}$ poeta, assim, impõe ao leitor um conceito, uma imagem de agente em torno da qual a elegia irá ser desenvolvida.

Muito já se discutiu acerca das personae poeticae constituídas na elegia romana, principalmente aquelas que envolvem diretamente a diç̧ão elegíaca no que diz respeito às pessoas do discurso, ou seja, quem fala (eu), com quem se fala (tu) e de quem ou do que se fala (ele ou aquilo). Nesse sentido, Sharrock (2000, p. 263) informa:

One of the major contributions of late republican and early imperial Latin poetry to the course of literature was the development of a subjective, first personal voice that seems to speak directly to the reader or to the addressee (pretending to ignore the reader), without the framing devices of narrative or dramatic presentation, and without even an explicit rhetorical separation of speaker and persona. This is not to say, of course, that the speaker of Augustan elegy straight forwardly is the poet, the man, the "real person" - far from it, for indeed, there are many levels of "persona" active in the communicative dynamics of elegy — but rather to suggest that the subjective stance offers a pose of immediacy which precisely occludes the artificiality of its own dynamics. ${ }^{15}$

É correto avaliar que a constituição de uma persona poética de caráter subjetivo e inserida na estrutura narrativa ou dramática sem qualquer marca ou mecanismo explícito é justamente uma marca

${ }^{15}$ Grifo nosso. 
característica dessa poesia. É também característico desse tipo de estrutura poética não apontar exclusivamente para um único "sujeito real", enunciador ou enunciatário da poesia, mas, antes, fazer desnudar uma dinâmica dialógica em que se observam diversos níveis de construção da personagem, que podem inclusive manter relação direta com o "vivido", mas também podem ser o reflexo de um verossímil construído a fim de por em evidência tipos relevantes, éthe significativos e observáveis por contiguidade na vida cotidiana de Roma nos séculos 1 a.C. e 1 d.C. Nesse sentido, os poetas elegíacos acabam por produzir os éthe que são, a meu ver, metonímicos, já que se apresentam como uma parte representando um todo.

Sharrock ainda explicita que a elegia properciana, por exemplo, traz à tona "truques de realismo" (tricks of realism) que não devem ser considerados como estruturas que menosprezam ou enfraquecem a poesia, ao contrário, tais truques enriquecem o envolvimento do leitor na própria poesia e oferecem uma riqueza de perspectivas que vão muito além da simples presença autoral e biográfica que possa estar ou não declarada na primeira pessoa. Assim, o "realismo" é "a construct which comes into being as an impression of reality and in a mimetic game between poet and reader" (SHARROCK, 2000, p. 264). O trabalho de Wyke (1987a e 1987b), secundado por Greene (1995), foi importantíssimo para a consolidação da ideia de jogo de Veyne, observando-se no caso das estudiosas a especificidade da construção da persona "Cynthia" como metáfora, ou melhor, personificação, da poesia elegíaca propriamente dita e "as a construct of the text whose apparent reality was in fact a reality effect" (SHARROCK, 2000, p. 264).

Tomando apenas personagens envolvidas na narrativa elegíaca e não aquelas que se apresentam como referenciais históricos dentro desse tipo de composição (como Mecenas, César, etc.), nos dois ou três primeiros livros de Propércio - isto depende se aceitamos a hipótese de divisão dos livros apresentada por Lachmann $-{ }^{16}$ uma gama vasta de personagens é apresentada, entre elas, um eu-elegíaco, a que se convencionou chamar Propércio, já que em 2.8 se apresenta como tal: sic igtur prima moriere aetate, Propetii?/ sed morere; interitu gaudeat illa tuo!, mas que desde o primeiro livro permanece inominado, apenas

${ }^{16}$ Acato a hipótese de Lachmann (1816), reformada por Lyne. Lyne (1998); Lyne (1998b) e, referendada por Murcia (2000); Martins (2015) e outros. 
identificando-se como o poeta, ou enunciador das elegias. Dessa forma, podemos pensar inicialmente em interlocutores variados, rivais, amigos ou amada, no livro 1 : Tulo $(1.1 .9 ; 1.6 .2 ; 1.14 .20 ; 1.22 .1)$; Cíntia (1.2.1; 1.3.21; 1.8.8; 1.11.1; 1.15.2; 1.17.5; 1.18.5; 1.19.1); em Basso (1.4.1); Galo (1.5.31; 1.10.5; 1.13.2; 1.21.1) e Pôntico (1.7.1; 1.9.26; 1.12.2). Embora no livro 2 essa variedade de personae diminua sensivelmente, o livro se abre com uma novidade para Propércio, o chamamento a Mecenas na elegia 2.1, apresentando explicitamente a filiação de sua poesia com o principado de Augusto por adesão ao mecenato, de sorte que o gênero elegíaco passa a fazer parte do rol de gêneros operados no círculo, ${ }^{17}$ entre os quais, podemos pensar no Horácio das Odes e dos Epodos ${ }^{18}$ ou no Virgílio das Bucólicas, das Geórgicas e da Eneida. Esta extração poética, a elegia erótica, passa assim a estar a serviço do principado de Otávio. Entretanto, além da apresentação desse interlocutor significativo, ${ }^{19}$ devese entender que o segundo livro opera a consolidação da construção de "Cynthia" como uma persona poética polissêmica.

Para que possamos entender a estrutura do jogo poético elegíaco, sob a perspectiva das personagens envolvidas, há que se entender que o ponto de referência essencial é sempre o enunciador poético, isto é,

\footnotetext{
${ }^{17}$ Miller (2001, p. 127) apresenta o seguinte argumento: "It is no accident that this book commences with a recusatio or that the figures of Maecenas and Augustus loom large over it. Propertius has begun to move in the imperial circle. This, however, does not mean that his poetry becomes less oppositional. Rather, to the extent that poetry referring to, or refusing to refer to, the emperor, Maecenas, and their coterie, is more prominent in this collection, then the recuperative pressures of the Roman Symbolic stand in proportionately sharper opposition to the erotic Imaginary's desire for asocial union (as exemplified in words like nequitia, inertia, etc.) that stands at the heart of elegiac discourse".

${ }^{18}$ HORÁCIO, Carm. 1.1.1; 1.20.5; 2.12.11; 2.17.3; 2.20.7; 3.8.13; 3.16.20; 3.19.3; 4.11.19 e HORÁCIO, Epod. 1.4; 3.20; 9.4 e 14.5.

${ }^{19}$ JOHNSON, 2012, p. 44: "How Maecenas himself supposed his newcomer would fit into his new surroundings is also difficult to guess at. But he apparently felt that he could persuade the passionate (and eccentric) young poet of love to transform himself into an ardent supporter of the princeps who would eventually reveal himself as an emperor, the brilliant and lucky politician who relied heavily on Maecenas for advice on various matters and not least for his fertile talents as master of political spin. That Maecenas was not slow in urging Propertius to add ardent civic advocacy to his repertoire of ardent representations is clear from the very first poem in the poet's new volume (2A), which is addressed to his powerful new friend".
} 
aquele que fala no discurso, ora apresentando um interlocutor em vocativo com quem se fala no discurso, ora referindo-se a uma terceira pessoa de quem se fala nesse mesmo discurso. Assim, o processo de imitação na elegia romana erótica é mediada pela primeira pessoa, ou mesmo, por ela obstruída, ainda mais quando temos a própria ausência de um quadro narrativo ou dramático que emoldure tal circunstância pragmática discursiva. Nesta circunstância, a primeira pessoa do discurso - o ego Propertius -, o falante, está no comando de toda a constituição discursiva, controlando a sintonia fina da área nebulosa entre realidade e ficção. Há que se lembrar que Propércio existe como persona historica, age dentro da elegia como um poeta, logo, é a tal ponto verossímil que duvidamos, muita vez, de que ele não seja concretamente real. E é justamente ele, o enunciador, que conduz a ação ora para o enfoque ficcional, ora para o real.

Fear, ao produzir um ensaio sobre o narrador elegíaco, procura, por sua vez, esclarecer a "dobra" existente na elegia, isto é, seu caráter binário (real x fictício). Ele busca examinar como esta figura narrativa, inserida na ficcionalidade da poesia erótica, encarna aspectos referenciais importantes de sua época. Ainda que seu ensaio esteja centrado no $3^{\circ}$ livro (ou $4^{\circ}$, a supor que são 5 livros) de Propércio, são válidas as características de um homem "no limiar da idade adulta", já que para o estudioso tal limiar é um ingrediente essencial da elegia. Esse momento de vida a que o narrador está sujeito na construção elegíaca permite ações que poderiam soar como indecorosas a homens mais velhos. É justamente o desenho desse jovem poeta que medeia as ações na narrativa properciana, vale dizer não só em Propércio, mas também nos dois primeiros livros de Tibulo e nos Amores de Ovídio, obras que Fear chama de "mainstream Roman elegy". O fundamento argumentativo apresentado são os conceitos de tirocinium adulescentiae de Sêneca ou de uacatio adulescentiae de Cícero (FEAR, 2005, p. 13-14).

Ao estabelecer o controle da situação de fala nas mãos de uma persona híbrida - real e fictícia -, o poeta, digamos, escancara as "portas" da ficcionalidade ${ }^{20}$ poético-elegíaca como que dando estatuto metapoético

\footnotetext{
${ }^{20}$ Apesar de focalizado sobre a narrativa dos séculos 19 e 20, são interessantes as palavras de Gallagher sobre o termo fiction. GALLAGHER, 2006, p. 337-338: “As this sense of the word gained greater currency, mainly in the eighteenth century, an earlier frequent meaning of 'deceit, dissimulation, pretense' became obsolete. Although consistently contrasted with the veridical, fictional narration ceased to be a subcategory
} 
ao paraklausithyron. A porta, fechada ou aberta, permite a invasão ou não do leitor, assim como permite, ou não, a entrada do poeta amante ou de seus rivais e/ou amigos. $\mathrm{O}$ fato, portanto, de haver a identificação entre o enunciador poético e a figura histórica do poeta imprime a essa ambiguidade um papel importantíssimo de ambivalência do construto poético.

\section{Cynthia}

Broadly speaking, literary representations of the female are determined both at the level of culture and at the level of genre: that is to say by the range of cultural codes and institutions which order the female in a particular society and by the conventions which surround a particular practice of writing. (WYKE, 1987b, 153)

Elaine Fantham apresenta uma pequena síntese acerca de como a imagem da mulher - e daí obrigatoriamente a imagem de Cíntia soa essencial - foi analisada pelos estudiosos da elegia erótica romana:

In Propertius' case Cynthia was still treated as reality; or at least fictionalized reality; hence the useful formulation of Lieberg: inspiration, subject and intended addressee, "zugleich Quelle, Gegenstand und Ziel"21 of Propertius' elegiac poetry, and the vivid recreation of the poet's mistress in the climactic twelfth chapter of Boucher. Then came a critical move to separate literature from life, with concentration on the poet's processes: Veyne reinterpreted the loved woman as a mere reflection of the poet lover's self-image, followed by Wyke for whom Cynthia passed from being the poet's subject to a "form of literary language," or "of poetic production", on which the elegist could exercise his Callimachean stylistic ambitions. Dispute over the fictionality or instrumentality

of dissimulation as it became a literary phenomenon. If the etymology of the word tells us anything, fiction seems to have been discovered as a discursive mode in its own right as readers developed the ability to tell it apart from both fact and (this is the key) deception".

${ }^{21}$ Fonte e objeto alvo. 
of "Cynthia" distracted from the primary study of how she was represented and how she was treated as representative of her sex. The elegist's attitude is important because Propertius himself shows so much interest in his contradictory reactions. (FANTHAM, 2006, p. 183)

Por sua vez, Johnson propõe sucintamente algumas possibilidades de leitura para Cynthia: a) uma mulher realmente amada pelo poeta (perdida, ou rejeitada, ou por quem foi rejeitado); b) uma colagem de diversas mulheres com quem o poeta teve alegrias e sofrimentos; c) um mecanismo textual improvisado a partir de mulheres que outros poetas eróticos inventaram ou amaram; d) ou um amálgama de todas estas possibilidades (JOHNSON, 2012, p. 40). Miller propõe, por seu turno, que a crítica se divide entre dois grandes grupos ao avaliar a figura feminina, ou a puella elegíaca (MILLER, 2013, p. 173). Para ele, temos, de um lado, scholars como Lyne, que preferem entender esta poesia como o reflexo do desejo dos elegíacos pelo "wholelove" e, de outro, como Wyke e Veyne, que "argued that puellae were not real women in literary guise, but textual constructs" (MILLER, 2013, p. 166). Afirma ainda que, entre Wyke e Veyne, observa-se que a imagem feminina é efetivamente um elemento importante na textualidade, mas enquanto Veyne defende que todos os amantes na elegia são ficções irônicas, Wyke teria uma visão mais nuançada que permitiu a determinação histórica do amante elegíaco por intermédio de outras imagens de mulher que circulavam contemporaneamente aos poemas.

Porém, a posição que me parece mais precisa hoje é a proposição do próprio Miller que, partindo da premissa de que não há acerto ou erro de interpretação, defende que as puellae são, sem dúvida, elementos textuais e, daí, serem pretextos em torno dos quais são construídas elaboradas coleções poéticas. Afirma que tais mulheres, pelo menos do jeito que as conhecemos, não existem fora do mundo estritamente escrito e, assim, são elas elementos organizados em torno das quais o cenário básico do amor elegíaco é construído, de sorte que este gênero poético não existiria sem elas. Alerta, entretanto, que textos e linguagens - matéria prima dessa construção poética - não são meros sistemas abstratos, ao contrário, "they are deeply embedded tools that exist only insofar as they are intelligible, useful and/or enjoyable by the inhabitants of their world" (MILLER, 2013, p. 167). Pode-se notar, a partir de Salústio e de outros autores, que os romanos acreditavam à época de Augusto que 
os mores haviam mudado e que tais mudanças estavam ligadas a uma liberalidade cada vez maior das mulheres romanas, tendo em vista as tradições republicanas que as constrangiam. Sob esta mesma perspectiva, Wyke esclarece que uma figuração feminina como a de Semprônia de Salústio seria impensável até segunda metade do $2^{\circ}$ século a.C. e ter sido somente a partir do nascimento do Império que discursos moralizantes, que associam uma conduta sexual feminina ímproba com a desordem social e política, passam a proliferar (WYKE, 1989a).

Por sua vez, Miller continua seu raciocínio, afirmando:

We also know that Augustus in his attempt at reform clearly believed that there had been a decline in the standards of moral behaviour, or at least that it was useful to portray himself as believing such. Moreover, he saw that the link between elegiac love poetry and moral decline was sufficiently credible that he could list the Ars Amatoria as one reason for Ovid's exile without appearing ridiculous. The puellae may be textual, but they have oddly real effects. (MILLER, 2013, p. 167)

Por fim, o scholar apresenta sua tese acerca destas figuras típicas da elegia erótica romana -, com a qual me alinho. Ele afirma que, no exame da figura feminina, a escolha entre ficção e realidade, entre textualidade e história, ou entre linguagem e referência no que diz respeito à puella elegíaca é sempre um erro, isto é, optar por um aspecto em detrimento de outro é sempre um equívoco nesse gênero textual, já que, penso eu, o confronto interno nessas estruturas binárias é o cerne do gênero elegíaco. Tomar Cynthia apenas como ficção, esquecendonos da realidade, ou vice-versa; observar Corina como textualidade, abrindo mão da história; ou mesmo, recuperar Delia, insistindo apenas nas referências a que remete e não levando em consideração a linguagem em que está construída; tudo isto acarreta um grande equívoco, digamos, exegético. Devemos pensar que essas mulheres só existem na medida em que elas funcionam no sistema textual conhecido como elegia erótica latina, e que o sistema só existia porque era inteligível para utilização dos habitantes de Roma no período. A questão não é somente quem eram as puellae, mas como elas funcionam e o que elas representam. E isso quer dizer: "Qual é o conjunto de valores que elas substituem nas economias textuais construídas pelas coleções poéticas em que estão figuradas?" (MILLER, 2013, p. 167). 
A relação estabelecida por Propércio entre a imagem da puella (Cynthia) e o poeta, isto é, entre o enunciador e um dos enunciatários, envolve movimentos mais complexos do que os que estão em jogo nas relações análogas em Catulo e Tibulo. Em Propércio, portanto, "the substitutions that characterize the poet's relation to puella evolve over time as his aesthetic practice, patronage relations and political affiliations change" (MILLER, 2013, p. 173). Assim, Cíntia é livro ou coleção de elegias; Cíntia é uma prostituta; Cíntia é a contrafação à política de austeridade moral proposta por Augusto. E é justamente esta multiplicidade de trocas que caracteriza o "jogo elegíaco" a que se refere Veyne e ao qual já me reportei. Zélia de A. Cardoso, para tratar da representação da mulher na poesia latina, precisamente adverte que:

Não podemos, portanto, considerar os textos literários como documentos totalmente válidos para o conhecimento de um contexto social, muito embora sejam eles produtos desse contexto. A obra literária espelha a sociedade, apresentando todos os defeitos e sofrendo todas as limitações próprias dos espelhos: deforma-a, inexoravelmente, e reduz-lhe as dimensões a um plano único. (CARDOSO, 2003, p. 264)

Se é certo que a ficcionalidade das elegias é algo inquestionável, também o é o fato de manter relação estreita com a realidade, como salienta a professora Zélia de A. Cardoso, ainda que apenas nos apresentando, como um resultado, não um dado ou imagem concreta ou "real", mas um verossímil, que está, assim, sujeito a distorções ou a ofuscamentos que se apresentam diante dos olhos do leitor como uma realidade possível e embaçada, portanto duvidosamente verdadeira. Assim, ao lermos estas imagens femininas, como a de Cíntia, devemo-las ler ou ver de acordo com restrições que supõem as referidas "substituições" a que se refere Miller.

Certo é que, sob uma perspectiva antiga, podemos observar a persona Cynthia comentada, pelo menos, por Apuleio e Marcial. Cynthia dissimula Hostia, que é uma identidade apresentada por Apuleio numa passagem da Apologia $^{22}$ em que relaciona diversas destinatárias da poesia

\footnotetext{
${ }^{22}$ APULEIO, Apol. 10: Habes crimen meum, Maxime, quasi improbi comis atoris de sertis et canticis compositum. hic illud etiam reprehendi animaduertisti, quod, cum aliis nominibus pueri uocentur, ego eos Charinum et Critian appellitarim. Eadem igitur opera accusent $C$. Catul $<l>$ um, quod Lesbiam pro Clodia nominarit, et Ticidam similiter, quod quae Metella erat Perillam scripserit, et Propertium, qui Cunthiam
} 
latina a celebridades da vida romana (MARTINS, 2009, p. 28). Ainda que o desvendamento do anonimato possa vir a ser apenas uma invectiva sobre a persona historica Hóstia, o ruído, o boato, pode explicitar uma espécie possível de recepção-juízo que se fez, em algum momento da história da Roma antiga, acerca das personae elegíacas. Não me parece justo pleitear que alguém seja uma Cíntia, Corina ou, até mesmo, Lésbia. Afinal, Lesbia nostra, Lesbia illa, illa Lesbia... (CATULO, 58. 1-2).

Tomemos dois momentos em que aquelas substituições podem ser reavaliadas no contexto histórico, contribuindo para a constituição da persona, sob uma perspectiva pragmática. Uma na elegia 2.6, em que Propércio busca caracterizar o êthos de Cíntia por contiguidade às imagens de Frina, Laís e Taís, e em 2.7, em que apresenta Cíntia feliz, já que houve a revogação de uma lei. Entretanto, antes de nos atermos à elegia 2.6, vale a pena observar os versos finais da elegia 2.5, já que esta dialoga no quadro da textualidade da coleção do segundo livro, em que diz o eu-elegíaco:

Scribam igitur, quod non umquam tua deleat aetas:

27

'Cynthia, forma potens: Cynthia, uerba leuis'.

Crede mihi, quamuis contemnas murmura famae,

hic tibi pallori, Cynthia, uersus erit. ${ }^{23}$

Parece-me que Propércio se vale do tema final dessa elegia (2.5) a fim de introduzir a referida amplificação do vitupério em 2.6, aproximando Cíntia de três preciosos exemplos da vida mundana. Esta relação entre as elegias da coleção imprime refinamento na narratividade, tendo em vista ser a narração uma coleta, uma recolha de poemas. Esses dois últimos dísticos da elegia denunciam, de um lado, o caráter de inscrição da persona Cynthia, que pode ser observada aqui epigraficamente como elaborada a partir de um monumento/documento, uma inscrição, à vista dos transeuntes, já que colocada à sua porta (YARDLEY, 1983, p. 364); e, de outro, delineada sob seu aspecto físico-moral, paralelamente, de maneira que temos em contraste forma $x$ uerba e potens $x$ leuis.

Tomemos agora o início de 2.6:

dicat, Hostiam dissimulet, et Tibullum, quod ei sit Plania in animo, Delia in uersu.

${ }^{23}$ PROPÉRCIO, 2.5.27-30: "Eu irei escrever, pois, o que em tua vida nunca se apagará:/ 'Cíntia, beleza ingente; Cíntia, diversão-palavras'./ Crê-me, ainda que desprezes os boatos da fama,/ esses versos, Cíntia, vão te deixar pálida”. 
Non ita complebant Ephyraeae ${ }^{24}$ Laidos aedis, ad cuius iacuit Graecia tota fores; turba Menandreae fuerat nec Thaidos olim tanta, in qua populus lusit Ericthonius; nec, quae dele[c] tas potuit componere Thebas, Phrynetam multis facta beata uiris. ${ }^{25}$

Os seis primeiros versos dessa elegia são importantes na constituição de uma das possibilidades da persona elegíaca Cynthia. $\mathrm{O}$ poeta faz referência a três mulheres - uma em cada um dos três dísticos - operando uma comparação tripla, linguisticamente construída pelas estruturas non ita... (v. 1) nec...tanta (v. 3 e 4) e nec...tam (v. 5 e 6). Essas três mulheres são comparáveis à Cynthia, que aparecerá nominada apenas no v. 40. Assim, Cíntia é superior à Laís, à Taís e à Frina. A primeira Laís - fez se curvar toda a Grécia diante de sua porta; com a segunda - Taís - toda Atenas lusit - brincou; e com os recursos auferidos por sua atividade econômica, a terceira - Frina - foi capaz de reconstruir Tebas destruída. Cíntia é enunciada na elegia como uma grande hipérbole feminina, construída por acúmulo. Portanto, essa amplificação opera o epidítico sob o viés do vitupério, já que a prostituição é o que une as três personagens do anedotário grego à persona elegíaca, sendo Cíntia a negatividade da probidade feminina. James defende, na verdade, que o papel desempenhado por Cíntia nas elegias é desenhado com antecedência por sua profissão e classe social. Vai além, defende que a puella é uma meretriz e, assim, o discurso elegíaco dedicado a ela tornase mais evidente se a entendermos como uma cortesã (JAMES, 2010, p. 315). De acordo com a New Pauly (NP 7.174), ${ }^{26}$ Laís era um nome corrente de prostitutas em Corinto; já Taís (NP 14. 358 $)^{27}$ era um nome de prostituta e epônimo de heroínas nas comédias de Afrânio, Hiparco e

\footnotetext{
${ }^{24}$ Antigo nome de Corinto.

${ }^{25}$ PROPÉRCIO, 2.6.1-5: "Não vinham assim à casa de Laís de Éfira,/ em cuja porta curvou-se toda a Grécia;/ nem outrora fora tamanha turba na de Taís de Menandro/ na qual brincou o povo de Erictônio;/ nem Frina, que pôde refazer Tebas destruída,/ tornou-se rica por ter tantos homens".

${ }^{26}$ EURÍPIDES, Med. 1346; ATENEU, 13.570c-d; OVÍDIO, Am. 1.5.12 e GÉLIO, 1.8.3. ${ }^{27}$ ATENEU, 13.576d-e; TERÊNCIO, Eu. 266-75 e MARCIAL, 14.187.
} 
Menandro; e Frina (NP 11.198) ${ }^{28}$ era a mais famosa meretriz reconhecida por sua beleza e perspicácia. Em seguida, tem-se:

Quin etiam falsos fingis tibi saepe propinquos, oscula nec desunt qui tibi iure ferant.

Me iunenum pictae facies, ${ }^{29}$ me nomina laedunt, me tener in cunis et sine uoce puer;

me laedet, si multa tibi dabit oscula mater, me soror et cum quae dormit amica simul: omnia me laedent: timidus sum (ignosce timori) et miser in tunica suspicor esse uirum.

His olim, ut fama est, uitiis ad proelia uentum ${ }^{30}$ est, 15 his Troiana uides funera principiis; ${ }^{31}$

Após as três comparações, a interlocutora é chamada a participar da cena elegíaca no v. 7 ([tu] fingis) e a própria ação dessa interlocutora é resumidora da principal atividade das prostitutas, ela finge, cria, inventa que existem falsos parentes a quem deve, por obrigação, beijos. Imagino aqui que a prostituição se supõe como um simulacrum do ato amoroso, já que é o teatro do ato amoroso, a supor o caráter pecuniário e obrigatório do exercício sexual. Este verso é auto-esclarecedor, ao propor que Cíntia inventa parentes a fim de justificar seus beijos, quin etiam falsos fingis tibi saepe propinquos. A relação entre falsos e fingis tem linguisticamente o valor de um acusativo de objeto interno, apesar de não possuírem relação etimológica. Entretanto, entendo que guardam estreita relação semântica, já que o fingere é o verbo da modelagem, da criação, da ficção e dele derivam fictio, figura, que, por própria natureza, já são falsas. Parece-me também que se pode ler esse verbo como um esclarecimento da própria construção poética dos caracteres envolvidos nessa narração. Fedeli, por

\footnotetext{
${ }^{28}$ HORÁCIO, Epod. 14.16 e TIBULO, 2.6.45.

${ }^{29}$ Pictae facies iunenum $=$ retratos de jovens.

${ }^{30}$ 2.3.35-6. HOMERO, Il. 3.156-7.

${ }^{31}$ PROPÉRCIO, 2.6.7-16: "Tu mesma, assim, ainda crias sempre falsos/ parentes que ficam, por direito, te beijando./ Ferem-me retratos de jovens e seus nomes, / eu sou uma doce criança no berço e sem fala./ Vão me ferir se muitos beijos tua mãe te der,/ e tua irmã e uma amiga quando juntas dormem contigo./ Tudo vai me ferir: sou um covarde - perdoa o temor -,/ infeliz, eu suspeito que há um homem sob tua túnica./ Por tais vícios, como diz a lenda, outrora, se foi/ a guerra, por tal causa, vês a chacina de Troia".
} 
seu turno, observa a aliteração em "s" e em "f” (FEDELI, 2005, p. 199), o que, a meu ver, chama a atenção do leitor para a relação que acabo de anotar. Acredito que esse mesmo verso (7) mantenha uma ligação estreitíssima com o v. 9, a saber, me iuuenum pictae facies, me nomina laedunt, dado que há outra referência a artes figurativas e sua conexão direta com caracteres que estão sendo construídos: o eu-elegíaco tem ciúme das pictae facies iuuenum e nomina iuuenum, esses nomina, nada mais são do que personae construídas por Propércio, como se fossem pinturas/esculturas (pictae facies/simulacra), isto é o nomen é a etiqueta, o título, a chancela da atividade engenhosa de modelagem/pintura (fingere) pingere) do poeta. Que nomes são esses? Cíntia, Propércio, Basso, Pôntico, Galo, Tulo, Laís, Taís, Mecenas, César...

Ainda entre os v. 9-14, o sujeito da enunciação elegíaca apresentase fragilizado, assume ter ciúmes até da mãe da amada, pois: miser in tunica suspicior esse uirum - "Infeliz, eu suspeito que há um homem sob tua túnica". O verbo laedere, em três formas diferentes (laedunt, laedet e laedent) se apresenta em poliptoto, repetição que amplifica seu sentido, por abranger dois tempos diferentes, o presente (laedunt) e o futuro (laedet e laedent), além de poder ter um sujeito singular ou plural, sobre o mesmo objeto da ação "me". Além desse poliptoto, descrito por Fedeli (FEDELI, 2005, p. 201), é mister observar também a anáfora de "me", constituída pela repetição duas vezes no v. 9, uma vez no v. 10, no v. 11, e no v.12 (cinco vezes em quatro versos), acrescida, é importante dizer, por um predicativo sujeito miser no v. 14, associado ao verbo sum, em primeira pessoa do singular, reconstruindo assim o interlocutor de Cíntia, cujas características são semelhantes às de Laís, Taís e Frina, apontadas nos v.1-6, afora aquela indicada no v. 2.5.28, como vimos.

As imagens construídas a que acabo de me referir produzem um efeito imediato no eu-elegíaco: elas laedunt, machucam, incomodam, ferem... O afectum constituído, portanto, é patético; a fictio produz o efeito de sentido necessário, porquanto está em jogo o confronto entre o eu-elegíaco e Cíntia. Curiosamente, tal pronome de primeira pessoa irá se referir no verso no v. 10 ao puer tener in cunis, uma criança doce num berço - imagem indicadora de fragilidade, pateticamente construída, que leio como uma ironia. $\mathrm{O}$ mesmo pronome terá como referente no v. 13 timidus (ignosce timori); e no v. 14 miser, que produz um tom absolutamente cômico, já que ele suspeita que exista alguém sob a túnica de Cíntia. O poeta finaliza a primeira seção da elegia dizendo 
que his olim, ut fama est, uitiis ad proelia uentum est,/ his Troiana uides funera principiis - "Por tais vícios, como reza a lenda, outrora se foi/ à guerra, por tal causa vês a chacina de Troia" (v. 15-16). Entre os v. 16-24, exemplos em que o amor provocou tragédias e exorta ao final a fidelidade da casa de Ulisses.

A terceira seção da elegia, entre os v. 25-42, como que busca a responsabilidade pela ação leviana das mulheres, entre as quais naturalmente se sobressai Cíntia. Contudo, o mais curioso é o responsável apontado, isto é, uma arte mimética (WILLIAMS, 2006, p. 301-305), a pintura, figurada nas casas romanas. Mas não a pintura de gênero elevado como a de Zêuxis, Polignoto, Timantes ou Apeles, antes a de gênero baixo, do rhyparographos (PLÍNIO, Nat. 35.112-3), da pintura de Páuson que deveria ser evitada pelos jovens (MARTINS, 2008b, p. 80-82). Vejamos:

Templa Pudicitiae quid opus statuisse puellis,

si cuiuis nuptae quidlibet esse licet?

Quae manus obscenas depinxit prima tabellas ${ }^{32}$

et posuit casta turpia uisa domo,

illa puellarum ingenuos corrupit ocellos

nequitiaeque suae noluit esse rudis.

A gemat in te $<$ ne $>$ bris, ista qui protulit arte turpia sub tacita condita laetitia!

Non istis olim uariabant tecta figuris:

tum paries nullo crimine pictus erat.(... $)^{33}$

Os v. 27-34 reproduzem, em certa medida, a preocupação esboçada por Aristóteles na Política (ARISTÓTELES, Pol. 1340a 28-

\footnotetext{
${ }^{32}$ Esse verso dialoga com o 2.12.1: Quaecumque ille fuit, puerum qui pinxit amorem. Nesse caso as mãos serão admiráveis, entretanto aqui são agentes de objetos vis, baixos, obscenos.

${ }^{33}$ PROPÉRCIO, 2.6.25-34: "O que levou as meninas a erguer templos à castidade,/ se casadas, lhes é permitido ser o que quiser?/ Qual foi a primeira mão que pintou obscenos quadros/ e pôs em casta casa torpes visões,/ essa corrompeu os ingênuos olhos das meninas e, rude,/ quis que elas conhecessem a sua devassidão./ Ah! Gema nas trevas, quem revelou com essa arte/ torpezas recônditas sob tácitos gozos/ outrora não colocavam nos tetos essas figuras:/ então, as paredes eram pintadas sem vício algum”.
} 
40), em que propôs que certos pintores não podem ser apresentados aos jovens, pois podem formar mal seu caráter. O curioso nessa passagem é o fato de o poeta assumir, como algo geral àquele contexto da elegia e de Roma - validando-se a tese de que os referentes são comungados pela recepção -, a devassidão, uma vez que essa já teria tomado conta da domus romana. É importante salientar que a domus, apesar de ser uma instituição privada por excelência, sempre esteve na base da representação pública, isto é, a cultura política romana faz migrar da esfera privada estruturas de pensamento para a esfera pública. Assim, aquilo que serve a domus serve à República ou ao Principado, da mesma forma que o pater familias tem seu espelho público no pater patriae. Gardner defende que a elegia constrói a casa (domus) como uma resposta a conceitos emergentes de família romana, uma instituição cuja constituição havia sido perturbada durante as guerras civis que precederam ao principado. Assim, ela é entendida como uma resposta literária e generalizada, embora não incontestável, na representação da vida familiar no discurso de Augusto (GARDNER, 2010, p. 454). Tanto Tibulo quanto Propércio dependem muito da domus como um recurso para moldar suas identidades poéticas. Além, obviamente, de ser a reconstrução da domus um elemento de cultura material que é recriado na elegia a serviço do jogo.

Voltando ao poema, parece-me que mais uma vez, nele, o poeta hiperboliza o vício, só que desta vez de forma coletiva, a fim de que o seu objeto de desejo especificamente vicioso se dilua na multidão. Assim, a devassidão (nequitia) não é um vício caracterizador de uma única pessoa somente, mas o de uma época. E, nesse sentido, é pertinente pensar que a elegia dialoga abertamente com a ética "construída ou real" de Augusto, no sentido de que este está preocupado com a restauração de padrões morais "perdidos" nos últimos anos da República. Outra questão que deve ser observada é, justamente, o fato de, na mesma elegia, Propércio valer-se da imago, para produzir um efeito negativo, lá as pictae facies (v.9) produzem dolor, dor; e aqui as tabullae obscenae, nequitia, devassidão.

O poema, portanto, opera dois vetores: um aproximando a imagem de Cíntia às imagens de prostitutas (v. 1-14); outro buscando as causas da vida devassa (v. 25-34). Assim, apesar de a tensão construída pela primeira figuração, hiperbolizando a figura da persona elegíaca, ser impessoalizada pela terceira seção do poema, esta mesma seção imprime um caráter coletivo à devassidão que não exclui Cíntia, ao contrário, a coloca num ponto axial do exemplário, digamos, devasso 
entre as mulheres romanas. Entretanto, o que parece ser mais evidente é que a construção da ficcionalidade impressa por Propércio, ao construir Cynthia ficta nesta elegia, encontra a sua contrafação "concreta e real" na textualidade, como que contribuindo para a produção de um verossímil Cynthia historica, já que tanto as famosas prostitutas gregas quanto o caráter decadente da sociedade romana são operados no âmbito de provas concretas, que estão na base da própria natureza argumentativa da história. ${ }^{34}$

Essa elegia, portanto, apresenta claramente: a) o tema da elegia latina erótica - a nequitia; b) a figuração da puella devassa e a devassidão como vício coletivo de época; e, por último e não menos importante, c) a área nebulosa do contato entre história e ficção, entre ficcionalidade e historicidade. Tal área, não devemos esquecer, é aquela em que se delineia o jogo elegíaco, em que se observam as trocas, ou substituições, observadas por P. A. Miller (2013). Ainda podemos pensar numa outra leitura para esta elegia, a supor - e aceito a hipótese - que Cíntia é metáfora de poesia/livro de poesia, e nesse caso Cíntia é prostituta por contiguidade. Logo, o eu poético, ou o poeta que vive às expensas da prostituição, nada mais seria do que um proxeneta, um rufião. Esta hipótese é defendida por Fear, em que apresenta o tropo horaciano das epístolas 1.17 e 1.18: "The dependent poet as a matrona fidelis rather than a leuis meretrix: a literary spouse rather than poetic whore" (FEAR, 2000, p. 218). T. Fear, mais adiante tratando da elegia, especialmente, diz que esta pode ser lida operando dois níveis de prostituição literária: num, o narrador elegíaco procura - sem sucesso - prostituir seus poemas por sexo internamente ao texto; noutro, o narrador externamente usa a apresentação de uma mulher venal para prostituir seus poemas fora do texto. Assim, o discurso elegíaco, ao construir figuras femininas prostituídas ou venais, não apenas literaliza a metáfora da promiscuidade textual e dos autores rufiões, como também tais imagens são usadas para, digamos, seduzir sua audiência e aumentar sua visibilidade pública de poeta (FEAR, 2000, p. 221).

Tomemos a elegia subsequente no livro $2 \mathrm{~A}$, a elegia 2.7 . O movimento narrativo apresentado pela elegia 2.7 , se a tomarmos - e assim sempre devemos fazer - tendo em vista o conjunto da coleção

${ }^{34}$ MARTINS, 2008a, p. 202-203; GINZBURG, 2002, p. 47-63; MARTNS, 2013, p. 253; WHITE, 2001, p. 97-116; MOMIGLIANO, 1981, p. 259-268. 
poética do livro $2 \mathrm{~A}$, é o movimento da confirmação do êthos devasso de Cynthia, uma vez que, se em 2.6 ela é apresentada como ponto axial da devassidão romana, em 2.7 referenda-se tal êthos a partir da constatação histórica, ou seja, Cíntia se sente feliz, pois a lei que previa a punição para os adúlteros foi revogada:

\section{Gauisa es[t] certe sublatam, Cynthia, legem, ${ }^{35}$ \\ qua quondam edicta flemus uterque diu, ni nos diuideret: quamuis diducere amantis non queat inuitos Iuppiter ipse duos.}

'At magnus Caesar'. Sed magnus Caesar in armis: 5 deuictae gentes nil in amore ualent.

Nam citius paterer caput hoc discedere collo, ${ }^{36}$ quam possem nuptae perdere †more $†$ faces, ${ }^{37}$ aut ego transirem tua limina clausa maritus, respiciens udis prodita luminibus. ${ }^{38}$

Além do seu valor poético, esta elegia nos mostra exatamente a fronteira entre a "realidade" e o "conto de fadas" em que a elegia erótica romana se situa, já que, de um lado, temos uma camada ficcional clara e bem construída da persona poetica e, de outro lado, um universo referencial concreto e explícito, representado por um diploma legal, do direito positivo romano em contraste com o direito natural. Propércio, portanto, a constrói, a partir de uma afecção de Cíntia, fictícia por excelência, gauisa es (estás feliz) a propósito da sublatam legem (lei revogada), concreta e real. Assim, a revogação da lei (em 28 a.C.) afeta

\footnotetext{
${ }^{35}$ SUETÔNIO, Aug. 34; TÁCITO, Ann. 3.26-8; D.C. 53.21.1; 54.16.1.

${ }^{36}$ OVÍDIO, Ep. 16.155-6; Pont., 2.8.65-7.

${ }^{37}$ Penso more nuptae como um genitivo objetivo. Parece-me que aqui temos uma construção que não fica tão clara em Português, pois, segundo a passagem, o amante mais facilmente se permitiria decapitar do que deixar de ter uma amante por causa da existência de uma esposa.

${ }^{38}$ PROPÉRCIO, 2.7.1-10: "É certo, Cíntia, te alegraste com o fim da lei/ pela qual, outrora editada, ambos choramos muito,/ caso nos separasse, ainda que nem mesmo Júpiter/ seria capaz de afastar, forçados, dois amantes,/ 'Mas César é grande!' grande é César nas armas,/ povos vencidos nada valem no amor./ Pois, mais facilmente eu perderia a cabeça/ do que seria possível perder o prazer pelo respeito à esposa/ ou eu mesmo, casado, passar por tua porta fechada,/ observando a tua traição com olhos úmidos".
} 
suas pernonae elegiacae, elas se alegram com o fato de uma norma legal, concreta, não mais existir. Nesta elegia Propércio constrói um enunciador contrário à ação político-social de Otávio, que encorajava o casamento e a constituição familiar (é uma precursora das futuras leis: Lex Iulia maritandis ordinibus de 18 a.C. e da Lex Papia Poppaea de 9 d.C.), em nome de uma coerência ficcional de sua obra e um decoro na constituição do êthos de suas personagens. Outro dado interessante é que o fim da vigência da lei ocorre pelos insistentes e constantes protestos da cidadania. Assim as recusas dos ciues, que se baseiam na imposição necessária de ter filhos e no controle das relações de adultério, podemos pensar, são consonantes às aspirações das personagens ficcionais, entretanto, distantes da relação de poder entre Otávio e os cidadãos e da relação Otávio e Propércio.

Sob a perspectiva da elaboração poética, v. 5-6 ecoa 1.9.10 plus in amore ualet Mimnermi uersus Homero, já que nesse verso temos a oposição verso de amor (Mimnermo) x verso de guerra (Homero) e naquele vemos amor x guerra. Assim, lá, no âmbito metalinguístico da poesia, recuperando a pragmática do texto, como afirmou Miller, e aqui, no âmbito da vida cotidiana, recuperando o elemento sobre o qual recaem as substituições, ou simplesmente, elementos referenciais que igualmente são apresentados na elegia. É interessante observar nos v. 4-6: a) o rebaixamento de Júpiter em relação a César e o rebaixamento de César em relação ao amor, isto é, o amar é sobrevalorizado, porquanto, ainda que Júpiter quisesse separar os amantes, não conseguiria, tampouco César, ainda que ele seja o maior guerreando, pois de nada adianta vencer batalhas diante do amor; b) é o curioso efeito dialógico produzido no v. 5, com o discurso direto sendo apresentado sem verbo dicendi. Tal construção, a meu ver, alimenta ainda mais o poder de César em relação a Júpiter, uma vez que discursivamente apresenta mais uma voz alheia ao texto a referendar a tese de seu poder maior.

\section{Amigos, amantes e poetas}

Depois de ter observado algumas possibilidades narrativas no que diz respeito à constituição do ego-elegíaco, enunciador dos poemas, e de Cíntia, um de seus destinatários nas elegias de Propércio e, salientando sua importância no que se convencionou chamar o "jogo elegíaco", passo a observar interlocutores masculinos a que Propércio faz referência no 
primeiro livro, sejam amigos, sejam inimigos ou rivais desenhados na estrutura narrativa como destinatários da elegia, apresentados ao leitor como chamamento que, como vimos, aproxima a elegia romana de uma prática de fala, além de lhe imprimir certo valor de acordo com as intenções do enunciador ao construir os éthe das personae poéticas. Aqui a seleção desses destinatários funda-se exclusivamente na constituição metapoética da elegia de Propércio, isto é, interlocutores que trazem à elegia o motivo ou tema da própria realização poética.

Citroni afirma que é óbvio e largamente reconhecido que a delimitação da função e do destino da elegia é somente uma de muitas convenções e materiais a partir dos quais o mundo elegíaco é construído e constituído. Daí, finaliza: "Ma è anche vero che questa convenzione, come e più di altre convenzioni elegiache, potrebbe d'altra parte avere un consistente fondamento nella realtà" (CITRONI, 1989, p. 93). A conclusão a que chega o estudioso não parece distante daquela defendida por mim nas páginas precedentes, isto é, o caráter binário da persona elegíaca que é, na verdade, uma retomada da tese de La Penna (1977, p. 214 et seq.). Citroni também deixa claro que o universo de referências reais, muito além de uma mera identificação biográfica - parece-me que esta questão, pelo menos aqui está superada -, circunscreve no universo poético de Propércio figuras que podem ser identificadas como o público real externo às elegias: "Il pubblico dei giovani che conoscono l'amore e che, s'intende, amano la poesia. L'elegia ci suggerisce così un suo pubblico delineato a immagine e somiglianza della cerchia stessa del poeta elegiaco" (CITRONI, 1989, p. 94). ${ }^{39}$ Continua afirmando que esse público externo figurado na elegia é como que uma dilatação do círculo do poeta, coerente com a ficção do mundo erótico da elegia. Assim, ao mesmo tempo que é uma ficção, também é o decalque de um mundo comungado pelo poeta e seus, digamos, "amici", salientando-se sempre que essa construção, como Cardoso apontou, pode ser deformada, ou simplesmente, um falseamento da realidade (CARDOSO, 2003). Nesse mesmo sentido, parecem-me precisas as palavras de Sharrock:

When we read the words "Tullus", "Bassus", "Ponticus", "Gallus", we are meant to respond to them as signifiers of Roman men, real people of whom a life-story can be told, who read Roman poems and looked at (loved and

${ }^{39}$ Grifo nosso. 
read) Roman girls. The presence of these friends gives an immediacy of presence to the poetry, a sense that we are involved in something real, but Propertian poetics refuses to bridge the gap between reality and fiction, preferring rather to interweave them in creative but tricky tension. Opposite the world of Roman men - real, living, active, immediate - stands the world of myth - distant, dead (or never-alive), artistic and literary, transcendent. ${ }^{40}$ (SHARROCK, 2000, p. 268)

Passo a observar aqui duas personae poeticae: Pôntico e Basso. Elas trazem à tona de forma precisa, além da discussão sobre a área nebulosa entre ficção e realidade evocada precipuamente pela e na elegia romana, outro aspecto essencial dessa poesia, isto é, a referência metalinguística cuja função é instruir os leitores sobre aspectos poéticos do gênero do qual esta faz parte, e/ou do qual é um exemplo. Além de instruir os leitores, posso dizer que a inserção da poesia como tema comprova a tese de que os fruidores dessa poesia tinham plena consciência das convenções que nela, elegia, eram operadas. Eu poderia somar a esses dois nomes o de Galo, já que, entre esses nomina, seria aquele sobre o qual teríamos em mãos mais informações. Entretanto, creio que a obviedade da seleção de Cornélio Galo poderia reduzir a ideia de jogo a que estaria sujeita a elegia, dada justamente a sua popularidade, fato que não ocorre nem com Pôntico, tampouco com Basso.

Observo as elegias 1.7 e 1.9 como um par temático que recupera a questão genérica em Roma no período, ao explorar o contraste existente entre a elegia e a épica (MARTINS, 2009, p. 69-81). Tanto em uma como em outra elegia, Propércio estabelece como interlocutor um poeta épico, Pôntico, como destinatário dos poemas, colocando-o, portanto, no centro desse poema como articulador, por assim dizer, da contenda entre os gêneros poéticos. Pôntico é um poeta anticalimaqueano típico, além de ser um amante que há de sofrer por amor (1.7) e que já sofreu (1.9). Assim, ele é, por si mesmo, determinador das questões envolvidas no conflito do poema: a) a impossibilidade de a poesia épica ser o gênero apto à vazão do sentimento amoroso personalizado; b) a falta de habilidade deste poeta épico, em especial, para extravasar sentimentos personalizados em sua poesia e c) o homem afetado pelo amor tardio. O fato de discutir poesia,

${ }^{40}$ Grifo nosso. 
fazendo poesia e apresentando uma persona na poesia que represente um gênero poético diverso, é importante para o estabelecimento do decoro elegíaco em cuja duplicidade reside sua principal característica, o jogo. Pôntico, por assim dizer, é um representante metapoético no e do jogo elegíaco, uma vez que ocupa, de um lado, o cerne referencial e real da discussão poética, digamos, historicamente referendada, já que isto é atestado pela cultura intelectual do período; de outro, é agente ficcional da narratividade properciana que rivaliza com o próprio enunciador do poema, Propércio, trazendo em si mesmo a tensão que pode existir entre gêneros poéticos.

Em 1.4, Basso é o interlocutor do eu-elegíaco que afirma que ele estaria assediando-o a fim de que abandonasse sua amada, Cíntia (v. 8), elogiando ao enunciador outras meninas (v.1-2). A ação de Basso, assim, é essencialmente discursiva, já que a prática do discurso é o fator que pode fazer seu interlocutor romper sua relação com a amada. Ainda que Propércio em momento algum situe Basso como poeta, ele o insere pragmaticamente numa ação discursiva e é certo, pragmaticamente, que o gênero de discurso que pode ser nocivo a alguém é o epidítico, já que nesse gênero os vícios podem ser operados, qualificando alguém. A suposta nocividade das palavras de Basso, entretanto, curiosamente advém do elogio, logo de um discurso carente de qualidades vituperiosas, mas pleno de louvores. Contudo, ainda que o discurso em si provoque a elevação de alguém - outras meninas - o efeito de sentido produzido por ele é negativo. Ao elogiar outras meninas a Propércio, o afasta de Cíntia e a aproxima dele, Basso, que nessa reconstrução reportada do discurso passa a ser um enunciador.

Sob o aspecto filológico, nada se sabe sobre Basso, a não ser o testemunho de Ovídio nos Tristia que, apesar de ser tão fictício quanto real, compromete-se verossimilmente com a prática discursivo-poética de Propércio, dado que o apresenta como um iambógrafo, além do fato de ser um frequentador de um círculo poético restrito ao qual se associam Ovídio, Propércio e Horácio e, nesse sentido, ainda teríamos no mesmo círculo a diversidade poético-genérica contemplada, uma vez que a poesia elegíaca, épica, iâmbica e lírica estão referenciadas nesse cânone ovidiano. Uma curiosidade sobre este dado é o fato de a historicidade dessas personae (Pôntico e Basso) nunca ter sido efetivamente questionada justamente porque Ovídio dá estatuto de realidade a elas, entretanto esquecem igualmente que esse poeta justamente toma para si a convenção elegíaca 
iniciada por Propércio, levando-a às últimas consequências. Diz Helsin: "Ovid was participating, with all the enthusiasm we would expect from him, in an elaborate poetic game on the nature of truth and fiction that Propertius had started long before" (HESLIN, 2011, p. 52).

Diz Ovídio:

Saepe suos solitus recitare Propertius ignes

iure sodalicii, quo mihi iunctus erat.

Ponticus heroo, Bassus quoque clarus iambis dulcia conuictus membra fuere mei.

Et tenuit nostras numerosus Horatius aures, dum ferit Ausonia carmina culta lyra. ${ }^{41}$

Assim, apesar de estes destinatários serem construções poéticas, eles servem como matrizes de um mundo concreto que cerca o enunciador da poesia erótica, a própria natureza de sua atividade poética que o caracteriza e a do círculo cultural-intelectual a que pertence. Minha hipótese pode, em certa medida, ser corroborada por Heslin, que defende que duas personae elegíacas figuradas por Propércio no primeiro livro são na verdade pseudônimos que transportam para o gênero elegíaco uma discussão metapoética presente em Horácio (HESLIN, 2011, p. 51). Assim, tanto Pôntico está baseado no modelo esboçado por Horácio na persona Alpino, ${ }^{42}$ que "encarna" a antítese calimaqueana da poesia, quanto Basso não seria nada mais, nada menos, que o próprio Horácio no curso de sua escritura dos iambos. Nesse sentido, a ideia proposta por Citroni ganha um amparo poético interessante, já que Horácio e Propércio participam do mesmo círculo e, seguramente, questões poéticas lá, se não eram discutidas, eram sim efetivadas a partir das composições dos poetas.

A proposição de Helsin está fundada na concepção de redende Namen, ${ }^{43}$ que na comédia são os nomina de personae que contêm em si mesmos a auto-decifração de seu êthos, por derivação etimológica. Eles devem ser tratados como evidentemente pseudônimos confeccionados

\footnotetext{
${ }^{41}$ OVÍDIO, Trist. 4.10.45-50: "Propércio, a quem estive ligado por laço de amizade,/ amiúde estava acostumado a cantar seu tesão./ Pôntico, os heróis, fora Basso preclaro/ pelos iambos. Esses foram meus doces comparsas,/ enquanto com culta lira ausônia Horácio/ harmonioso deteve meus ouvidos".

${ }^{42}$ HORÁCIO, Serm. 1.10.36-7. HORÁCIO, Serm. 2.5.40-1.

${ }^{43}$ Redende Namen: expressão cunhada por G. E. Lessing que observa que há na comédia nomes cuja origem etimológica se aproxima de suas características no enredo.
} 
a fim de incorporar um molde poético bem-humorado que contribui na composição do êthos da persona cômica. Assim, o estudioso, associando a épica à metáfora do mar, chega à conclusão que Ponticus só poderia ser um poeta épico, afinal seu nome deriva de pontus. Além disso, Pôntico encarnaria o rival de Calímaco, Antímaco de Cólofon. Enquanto Calímaco faz uma poesia como antípoda de Antímaco, Propércio escreve no caminho oposto ao de Pôntico. Por sua vez, Basso, ainda segundo a hipótese de Helsin, teria origem numa palavra de origem no osco, que, apesar de não ser utilizada no latim clássico, está na base dos termos baixo, bajo, bas, basso, em português, espanhol, francês e italiano respectivamente (HESLIN, 2011, p. 56). Afirma ainda que tal palavra teria sofrido o fenômeno do "gap-classical" e, portanto, saído do osco e do latim arcaico e chegado ao romance, mas não sem antes ter passado por um latim "subliterário" na época clássica. Salienta, a fim de justificar esta hipótese, o orgulho horaciano pela origem da Venúsia (osca, portanto), além de este fato o associar a uma origem humilde (HELSIN, 2011, p. 57-58).

Seja como for, tanto o exemplo de Pôntico quanto o de Basso funcionam como registros metapoéticos que alargam o espectro da fronteira do jogo elegíaco e referendam uma utilização específica da persona elegíaca na constituição desse gênero singular romano. Um e outro asseguram-se como verossímeis, calcados numa possível realidade, especificamente numa realidade literária augustana. $\mathrm{O}$ mesmo ocorre com Cíntia, já que indubitavelmente frequenta o âmbito real-concreto do gênero poético como cultura intelectual do período; ela é o livro de elegias de Propércio e, também, é um referente explícito, associado à ficcionalidade elegíaca, portanto uma persona típica da área nebulosa em que se dá o jogo elegíaco e da própria elegia romana, como gênero singular romano. ${ }^{44}$

${ }^{44}$ Este artigo apresenta resultados parciais da pesquisa realizada por mim, como Visiting Fellow, junto ao departamento de Classics da Yale University, entre 2013 e 2014, financiada pela FAPESP. Agradeço a colaboração dessa Universidade que me franqueou a Classics Library no Phelps Hall, 24 horas por dia, 7 dias por semana, e também, a Sterling Library e suas "facilities". Também agradeço o apoio do meu amigo, Kirk Freudenburg, e dos colegas, Niek Jenssen, Benjamin Jerue, Collin McCaffrey e Mike Zimm do staff de Yale. Agradeço também aos editores de Nuntius Antiquus pelas correções e sugestões. 


\section{Referências}

ALLEN, A. W. "Sincerity" and the Roman Elegists. $C P h$, Chicago, vol. 45, n. 3, p. 145-160,1950.

BARCHIESI, A. Rituals in ink: Horace on the Greek lyric tradition. In: DEPEW, M.; OBBINK, D. (org.). Matrices of genre: authors, canons, and society. Cambridge, Mass: Harvard University Press, 2000, p. 167-182. BOUCHER, J.-P. Études sur Properce: problèmes d'inspiration et d'art. Paris: Boccard, 1965.

CAIROLLI, F. P. Marcial Brasileiro. 2014. 498p. (Tese de doutorado). São Paulo: FFLCH-USP, Universidade de São Paulo, 2014.

CARDOSO, Z. A. A representação da mulher na poesia latina. In: FUNARI, P. P. A.; FEITOSA, L. C.; SILVA, G. J. (org.). Amor, desejo e poder na Antiguidade: relações de gênero e representações do feminino. Campinas: Unicamp, 2003, p. 261-285.

CITRONI, M. Dedicatari e lettori della poesia elegiaca. In: CATANZARO, G.; SANTUCCCI, F. (org.). Tredici secoli di elegia latina. Assisi: Accademia Properziana del Subasio, 1989, p. 93-144.

CONTE, G. B. Sagio. In: OVIDIO. Rimedi contro l'amore. A cura di Caterina Lazzarini con un saggio di Gian Biagio Conte. Venezia: Marsilio, 1986, p. 49-50.

FANTHAM, E. The image of woman in Propertius' poetry. In: GÜNTHER, H.-Ch. (org.). Brill's companion to Propertius. Leiden: Brill, 2006, p. 183-198 (DOI: 10.1163/9789047404835_009).

FARRELL, J. Calling out the Greeks: dynamics of the elegiac canon. In: GOLD, B. K. (org.). A companion to the Roman love elegy. Malden: Wiley-Blackwell, 2012, p. 11-24 (DOI: 10.1002/9781118241165.ch1).

FEAR, T. The poet as pimp: elegiac seduction in the time of Augustus. Arethusa, Baltimore, vol. 33, p. 217-240, 2000.

FEAR, T. Propertian closure: the elegiac inscription of the liminal male and ideological contestation in Augustan Rome. In: ANCONA, R.; GREENE, E. (org.). Gendered dynamics in Latin love elegy. Baltimore: The Johns Hopkins University Press, 2005, p. 13-40.

FEDELI, P. Properzio elegie libro II: introduzione, testo e commento. Cambridge: Francis Cairns Publications Ltd., 2005. 
FOUCAULT, M. A arqueologia do saber. Trad. Luiz Felipe Baeta Neves. Rio de Janeiro: Forense Universitária, 1995.

GALLAGHER, C. The rise of fictionality. In: MORETTI, F. (org.). The novel, volume 1: history, geography, and culture. Princeton: Princeton University Press, 2006, p. 336-363.

GARDNER, H. H. The elegiac "domus" in the early Augustan Principate. $A J P h$, Baltimore, vol. 131, n. 3, p. 453-493, 2010.

GIBSON, R. Love elegy. In: HARRISON, S. (ed.). A companion to Latin literature. Malden/ Oxford/Victoria: Blackwell Publishing, 2005, p. 159-173.

GINZBURG, C. Relações de força. Trad. Jônatas Batista Neto. São Paulo: Cia. das Letras, 2002.

GREENE, E. Elegiac woman: fantasy, materia, and male desire in Propertius 1.3 and 1.11. AJPh, Baltimore, vol. 116, p. 303-318, 1995.

HESLIN, P. Metapoetic pseudonyms in Horace, Propertius and Ovid. $J R S$, London, vol. 101, p. 51-72, 2011.

JAMES, S. L. "Ipsa dixerat": women's words in Roman love elegy. Phoenix, Toronto, vol. 64, n. 3/4, p. 314-344, 2010.

JOHNSON, W. R. Propertius. In: GOLD, B. K. (org.). A companion to the Roman love elegy. Malden, MA: Wiley-Blackwell, 2012, p. 39-52.

LA PENNA, A. L'integrazione difficile. Torino: Einaudi, 1977.

LACHMANN, K. (org.). Sexti Aurelii Propertii Carmina. Leipzig: Gerhard Fleischer, 1816.

LIEBERG, G. Die Muse des Properz und seine Dichterweihe. Philologus, Berlin, vol. 107, p. 116-129, 1963.

LOWRIE, M. Inside out: in defense of form. TAPhA, Baltimore, vol. 135, p. 35-48, 2005 (http://www.jstor.org/stable/20054119).

LYNE, R. O. A. M. The Latin love poets from Catullus to Horace. Oxford: Oxford University Press, 1980.

LYNE, R.O.A.M. Propertius 2.10 and 11 and the structure of books " $2 \mathrm{a}$ ' and '2b". JRS, London, vol. 88, p. 21-36, 1988a.

LYNE, R.O. A. M. Introductory poems in Propertius 1.1 and 2.12. CCJ, Cambridge, vol. 44, p. 158-181, 1988b. 
MADER, G. Amphion and Orpheus in Propertius I, 9? AC, Paris, vol. 61, p. 249-254, 1992.

MARTINS, P. Sexto Propércio - monobiblos: éthos, verossimilhança e fides no discurso elegíaco do século I a.C. 1996. 133 p. (Dissertação de mestrado). São Paulo: FFLCH-USP, Universidade de São Paulo, 1996.

MARTINS, P. Breve história da crítica da literatura latina. Classica, São Paulo, vol. 21, n. 2. p. 189-204, 2008a.

MARTINS, P. Polignoto, Páuson, Dionísio e Zêuxis: uma leitura da pintura grega clássica. Phaos, Campinas, vol. 8, p. 75-98, $2008 \mathrm{~b}$.

MARTINS, P. Elegia romana: construção e efeito. São Paulo: Humanitas, 2009.

MARTINS, P. Pictura loquens, poesis tacens: limites da representação. 2013. 345 p. (Tese de livre-docência). São Paulo: FFLCH-USP, Universidade de São Paulo, 2013.

MARTINS, P. Ekphrasis, digression and elegy: a reception of Propertius ' second book (texto inédito, 2015).

MILLER, P. A. Why Propertius is a woman: French feminism and Augustan elegy. CPh, Chicago, vol. 96, n. 2, p. 127-146, 2001 (http:// www.jstor.org/stable/1215485).

MILLER, P. A. The "puella": accept no substitutions! In: THORSEN, T. S. (org.). The Cambridge companion to Latin love elegy. Cambridge: Cambridge University Press, 2013, p. 166-179.

MOMIGLIANO, A. The rhetoric of history and history of rhetoric: on Hayden White's tropes. In: SHAFFER, E.S. (org.). Comparative criticism: a yearbook. Cambridge: Cambridge University Press, 1981, p. 259-268 (vol. 3).

MOST, G. W. The languages of poetry. New literary history textual interrelations, Baltimore, vol. 24, n. 3, p. 545-562, 1993.

MURGIA, C. E. The division of Propertius 2. MD, Pisa, vol. 45, p. 147242, 2000.

REINHARDT, T. Propertius and rhetoric. In: GÜNTHER, H.-Ch. (org.). Brill's companion to Propertius. Leiden: Brill, 2006, p. 199-216.

ROSATI, G. Il rivale, o il triangulo del desiderio. In: SANTINI, C.; SANTUCCI, F. (org.). I personaggi dell'elegia di Properzio. Assisi: Accademia Properziana del Subasio, 2008, p. 251-272. 
SHARROCK, A. Constructing characters in Propertius. Arethusa, Baltimore, vol. 33, n. 2, p. 263-284, 2000.

SHARROCK, A. The "poeta-amator", "nequitia" and "recusatio". In: THORSEN, T. S. (org.). The Cambridge companion to Latin love elegy. Cambridge: Cambridge University Press, 2013, p. 151-165.

VASCONCELLOS, P. S. Esquecer Veyne? Nuntius Antiquus, Belo Horizonte, vol. 7, n. 1, p. 105-118, 2011.

VEYNE, P. L'élégie érotique romaine. Paris: Seuil, 1983.

VEYNE, P.A Elegia erótica romana: o amor, a poesia e o Ocidente. Trad. Maria das Graças Nascimento e Milton Nascimento. São Paulo: Brasiliense, 1985.

WALSH, R. Fictionality and mimesis: between narrativity and fictional worlds. Narrative, Columbus, vol. 11, n. 1, p 110-121, 2003.

WHITE, H. Texto histórico como artefato literário. In: WHITE, H. Trópicos do discurso: ensaios sobre a crítica da cultura. Trad. Alípio Correia de Franca Neto. São Paulo: Edusp, 1994, p. 97-116.

WILLIAMS, M. F. Propertius on art (Prop. III, 9, 9-16; II, 3, 41-44; II, 6, 27-34; II, 12, 1-12; II, 31): epigram, Aristotle, and the new Posidippus (P. Mil. Vog1. VIII, 309, Pos. X, 8-XI, 5 Bastianini = 62-70 AB). In: DEROUX, C. (org.). Studies in Latin literature and Roman history, XIII. Brussells: Latomus, 2006, p. 291-314.

WILSON, M. The politics of elegy: Propertius and Tibullus. In: DOMINIK, W.; GARTHWAITE, J.; ROCHE, P. A. (org.). Writing politics in imperial Rome. Brill: Leiden, 2009, p. 173-202.

WYKE, M. Written woman: Propertius' "scripta puella". JRS, London, vol. 77, p. 47-61, 1987a.

WYKE, M. The elegiac woman at Rome. PCPhS, Cambridge, vol. 33, p. $153-178,1987 b$.

WYKE, M. Mistress as metaphor in Augustan elegy. Helios, Austin, vol. 16, p. 25-47, 1989a.

WYKE, M. In pursuit of love, the poetic self and a process of reading: Augustan elegy in the 1980s. JRS, London, vol. 79, p. 165-173, 1989 b. WYKE, M. Roman mistress: ancient and modern representations. Oxford: Blackwell. 2002. 
YARDLEY, J. C. The poetic attack on Cynthia: Propertius 2.5 27-8. RhM, Köeln, vol. 126, p. 364-365, 1983 (http://www.rhm.uni-koeln.de/126/MYardley.pdf). 